\title{
Appropriate Target Interactions Prevent Abnormal Cytoskeletal Changes in Neurons: A Study with Intra-Sciatic Grafts of the Septum and the Hippocampus
}

\author{
Laurie C. Doering \\ Division of Anatomy, McMaster University, Hamilton, Ontario, Canada L8N $3 Z 5$
}

Transplantation of embryonic CNS regions into the PNS provides an opportunity to study temporal and spatial changes in the cytoskeleton that are associated with aging and neurodegenerative diseases. In this study, the fetal septum was transplanted alone or with the hippocampus into the sciatic nerves of young adult rats to determine whether the proper central neural target could prevent the expression of abnormal cytoskeletal changes. The substantia nigra, a nontarget area of the septum, served as control co-grafts. After $1,3,6,12$, and 18 months of survival, the grafts were examined by immunocytochemistry with antibodies to phosphorylated and nonphosphorylated neurofilaments, microtubule-associated proteins (MAPs), and glial fibrillary acidic protein (GFAP).

Subpopulations of neurons in the septal transplants expressed CAT and the NGF receptor (192-IgG). Long-term (12-18 months) expression of these two markers was only observed when the septum was combined with the hippocampus.

Although isolated single grafts of septum survived within the PNS substratum, significant neuronal loss, extensive graft shrinkage, and aberrant cytoskeletal immunoreactivity were prominent in the long-term group. Changes that reflected an aging process included the ectopic expression of phosphorylated neurofilaments in neuronal perikarya, swollen axons, and a loss of MAP2 immunoreactivity that paralleled dendrite regression. In addition, abnormal "curly" fibers in the neuropil were also immunolabeled with an antibody directed against tau (5E2). Introduction of hippocampal cografts increased the final size of the septal transplants and prevented the cytoskeletal changes that accompanied the degeneration in the single septal grafts. The degree of GFAP immunostaining in the septum corresponded with advancing graft age and was minimized when grafted with the hippocampal formation. When the septum was combined with the substantia nigra, the grafts also underwent shrinkage and no protective influence from aberrant cytoskeletal staining was observed.

These experiments exemplify the importance of an ap-

\footnotetext{
Received Oct. 28, 1991; revised Mar. 23, 1992; accepted Mar. 25, 1992.

This work was supported by grants from the J. P. Bickell Foundation and The Parkinson Foundation of Canada. I thank E. M. Johnson Jr., J. N. Wood, and K. S. Kosik for their generous gifts of the 192-IgG, RT97, and 5E2 monoclonal antibodies, respectively.

Correspondence should be addressed to Dr. L. C. Doering, Division of Anatomy, HSC 1R1, McMaster University, 1200 Main Street West, Hamilton, Ontario, L8N 325 Canada.

Copyright $\odot 1992$ Society for Neuroscience $0270-6474 / 92 / 123399-15 \$ 05.00 / 0$
}

propriate CNS neural target on the maintenance of long-term cholinergic neuron survival and normal morphology at the cytoskeletal level and illustrate the usefulness of these CNSPNS constructs to examine conditions that influence the cytoskeleton.

Embryonic CNS tissue has an inherent potential to grow when experimentally grafted to intra- and extracerebral locations $(\mathrm{Ol}$ son et al., 1983; Björklund and Stenevi, 1984). Fetal tissue will continue to develop, differentiate, and form specific connections with the host CNS subsequent to transplantation procedures. When regions of the fetal CNS are placed into the PNS (e.g., sciatic nerves), neural precursors also continue to divide and differentiate. Initially, the neuronal and glial morphological characteristics of CNS grafts within peripheral nerves are normal (Doering and Aguayo, 1987). Subpopulations of cells in chronic transplants, however, are affected by the unusual environmental circumstances of the PNS and show filamentous changes that correspond to cellular modifications in the aging nervous system and in neurodegenerative diseases (Doering, 1991). Spatial and temporal changes in the cytoskeletal components within the axonal, dendritic, and somatic compartments of these CNS transplants are routinely studied by immunocytochemistry.

The technique of transplanting fetal CNS into the PNS can be used to test the effects of selected factors on the survival of specific neuronal groups and to examine in detail the sequence of various cytoskeletal modifications that parallel neuronal death. Futhermore, flexibility is offered to combine different regions within the nerves and then study the grafted tissues at desired time points.

The present study examined the embryonic septal and hippocampal regions within the PNS. Specifically, these experiments were performed to assess the role of target and nontarget tissues on the long-term survival and staining patterns of cytoskeletal filaments in septal/diagonal band neurons. The results show that in contrast to shrinkage, neuronal loss, and the development of aberrant cytoskeletal features in single septal grafts, when combined with the hippocampus the septal transplants remained at a relatively constant size and consisted of neurons with normal cytoskeletal immunostaining patterns.

\section{Materials and Methods}

All animal experimentation adhered to the guidelines established by the Canadian Council on Animal Care and by the Animal Research Ethics Board of McMaster University.

Neural transplantation. Inbred Lewis rats (Charles River Laboratorics) were used for the experiments. The fetal tissues were taken from 


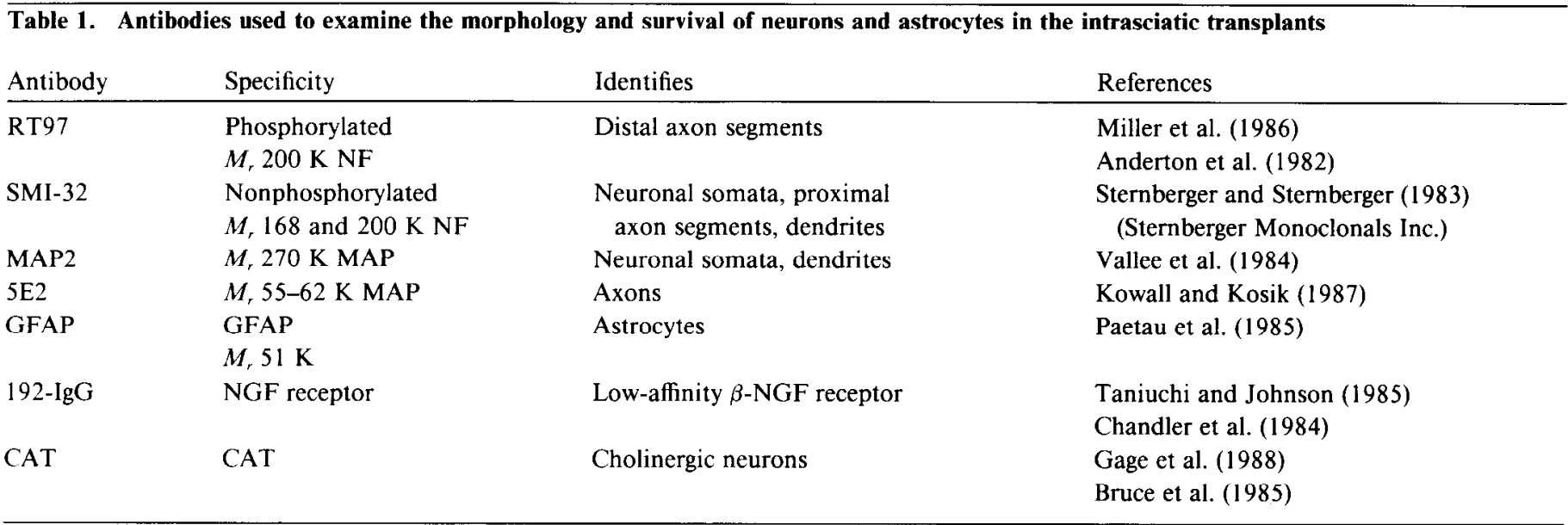

NF, neurofilament.

timed pregnant females on embryonic day 15 (E15) for the basal forebrain region (medial septal/diagonal band nuclei) and for the substantia nigra region. The hippocampal formation was removed from E16-E18 fetuses. The embryos were taken from deeply anesthetized animals that were given an overdose of Somnotol. Under a dissecting microscope the appropriate regions were dissected (Seiger, 1985) with finc forceps in sterile lactated Ringer's solution.

The recipient animals were given an intraperitoneal injection of Somnotol and the right sciatic nerve was exposed. The nerve was cut at the region of the sciatic notch 1 week prior to the grafting procedures. This nerve transection step clears the endogenous host axons and creates an internal peripheral nerve environment that allows easy injection of the grafts with minimal physical damage to the nerves or the embryonic tissues.

For transplantation, the epineurium of the sciatic nerves was cut with microscissors to allow entry of the glass tuberculin syringe $(0.25 \mathrm{ml})$ needle. The grafts were aspirated into the end of the needle and then pressure injected into the core of the nerves. This procedure permitted placement of the grafts within the host nerves at desired locations, and the final position could be achicved within $1.0-2.0 \mathrm{~mm}$ of the needle tip. The hippocampal or substantia nigra grafts were positioned distally in the nerves, and the septal grafts were placed in the proximal region of the nerve about $2.0-3.0 \mathrm{~cm}$ from the hippocampal or substantia nigra transplants. The location of the tissues was marked with 10-0 suture in the epineurium.

The transplants were examined after 1 and 3 months (short term) and $6,9,12$, and 18 months (long term) of survival. A total of 14 single septal grafts, 11 single hippocampal grafts, 9 co-grafts of septum and hippocampus, and 5 co-grafts of septum and substantia nigra were analyzed.

Retrograde axonal tracing. To confirm axonal extension from the grafted septal neurons in the peripheral nerves, rhodamine- $\beta$-isothiocyanate (RITC) was used as a retrograde tracer. In four anesthetized animals, the nerves were cut at the midway point between the septum and the hippocampus. A $2.0 \mathrm{~mm}^{2}$ piece of Gelfoam (Upjohn) soaked in a rhodamine- $\beta$-isothiocyanate (RITC) solution was applied to the cut nerve ends for approximately $30 \mathrm{~min}$. The RITC solution consisted of $20 \mu \mathrm{l}$ of dimethyl sulfoxide and $980 \mu \mathrm{l}$ of saline with $25.0 \mathrm{mg}$ of RITC purchased from Sigma (Thanos et al., 1987). The nerve endings were rinsed with saline and the muscles and skin closed. The animals were fixed with $4.0 \%$ paraformaldehyde in $0.1 \mathrm{M}$ phosphate buffer (PB) 12 $24 \mathrm{hr}$ after exposure to the RITC and the grafts were sectioned as described in the following immunocytochemistry and histology section.

Immunocvtochemistry and histology. Subsequent to intracardiac perfusion with $4.0 \%$ paraformaldehyde in PB, the sciatic nerves were dissected and postfixed in the same type of fixative at $4^{\circ} \mathrm{C}$ overnight. The following morning the nerves were cryoprotected in $30 \%$ sucrose and then immersed until frozen in a solution of isopentane cooled to $-55^{\circ} \mathrm{C}$ with liquid nitrogen. Longitudinal or cross sections of the grafts were cut at $10-15 \mu \mathrm{m}$ in thickness on a cryostat and they were collected in $0.01 \mathrm{M}$ phosphate-buffered saline (PBS). All immunocytochemical dilutions were made with PBS. Sections were initially floated in $3.0 \%$ bovine serum albumin in PBS to reduce nonspecific binding of the antibody immunoglobulins. Free-floating sections were then rinsed in PBS and incubated with the primary antibodies overnight at $4^{\circ} \mathrm{C}$. The antibodies used in this study are listed in Table 1. Subsequent to incubation with the primary antibodies, the sections were thoroughly rinsed and floated in goat anti-mouse IgG sccondary antibodies conjugated to fluorescein (Jackson Immunoresearch Inc.). Control sections were checked by substituting normal serum for the primary antibodies and by the omission of the primary antibodies from the reaction. No specific immunofluorescence was observed in the control sections.

The sections were placed on glass microscope slides, rinseci with distilled water, dried, and then covered with a 1:1 ratio of glycerol and sodium carbonate buffer ( $\mathrm{pH} 9.0$ ). The buffer contained $0.04 \% \rho$-phenylenediamine to reduce the fading effect of the UV light on the fluorescent probes. An epifluorescence microscope equipped with rhodamine and fluorescein filter packs was used to observe the immunoreactivity. For approximately one-half of the transplants, alternate sections were stained with $1.0 \%$ cresyl violet to estimate the graft volumes and quantitate the neuronal populations.

Four grafts wcre fixed with $1.0 \%$ paraformaldehyde, $2.0 \%$ glutaraldehyde in $0.1 \mathrm{M} \mathrm{PB}$. After $24 \mathrm{hr}$ of fixation, the tissues were dehydrated through an ethanol series and embedded in a mixture of Epon-Araldite plastic. Semithin sections $(1.0 \mu \mathrm{m})$ were cut, stained with toluidine blue, mounted on glass microscope slides, dehydrated, and coverslipped with DPX.

\section{Results}

\section{Gross morphology of the nerves}

At the time of dissection, the grafts were observed as yellowish masses in the center of the peripheral nerves. In contrast to the focal distention of the host nerves by the short-term grafts, the nerves containing the long-term single septal transplants were very narrow and atrophied in appearance. The chronic grafts of combined septum and hippocampus or the single hippocampal tissues that survived for up to 1.5 years were still identifiable as regional enlargements within the sciatic nerves. Older transplants were dark yellow in comparison to the pale yellow appearance of the short-term preparations. Figure 1 depicts the relative final size of the septum after 1 year when co-grafted with either the hippocampus or the substantia nigra.

\section{Axonal tracing}

The two short-term and two long-term septal grafts processed for retrograde tracing consisted of neurons that were labeled with granules of RITC. A perinuclear distribution of the RITC granules characterized the majority of cells (Fig. 2). Occasional processes were filled with the fluorescent tracer. 

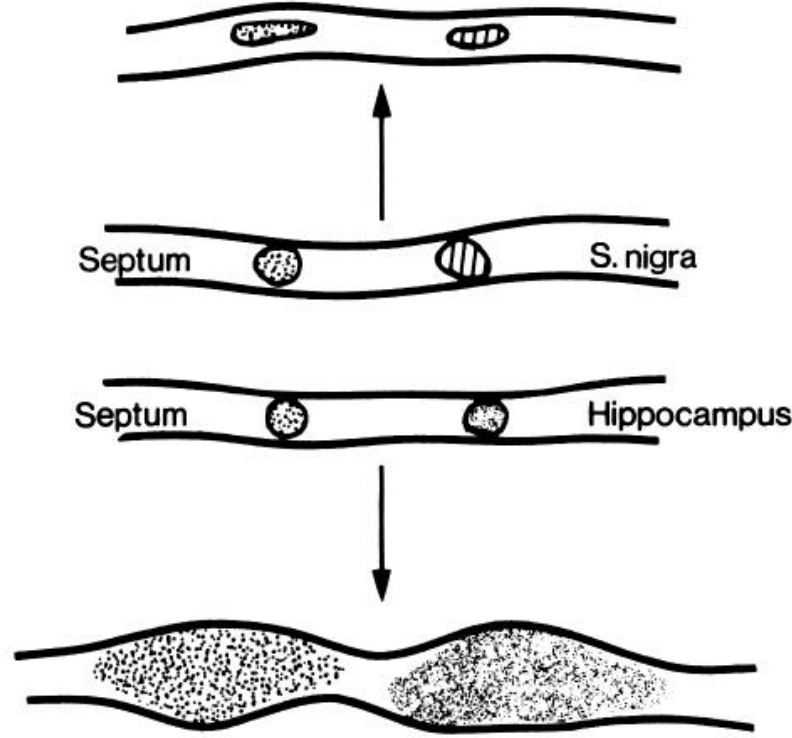

Figure 1. Schematic representation of the final graft sizes when introduced into the sciatic nerves. The effect of a target (hippocampus) or nontarget (substantia nigra) on the size of the septal graft is illustrated.

\section{Immunocytochemistry and histology}

\section{Single septal grafts}

Bipolar neurons were identified with the 192-IgG (NGF receptor) and CAT antibodies in the short-term (Fig. 3a,c), but not the long-term septal grafts (Fig. 3). The long bipolar axis of these cells was usually oriented parallel to the long axis of the nerve, and their morphology was similar to positive cells in situ. A moderate density of processes with $192-\mathrm{IgG}$ immunoreactivity to the NGF receptor were distributed throughout the transplants. Expression of $192-\mathrm{IgG}$ in the peripheral nerve matrix was extensive when examined at 1 month, but diminished as a function of increasing age (Fig. 4). In addition to a reduction in transplant volume (Table 2), the loss of neurons was exceptionally apparent (Table 3 ) when comparing the short- and long-

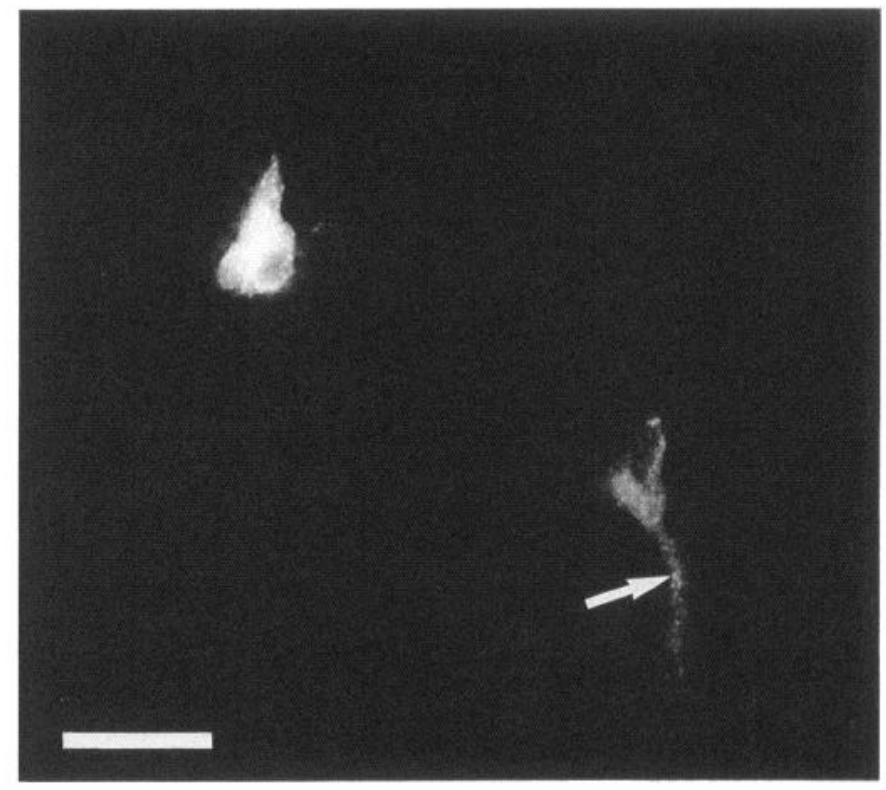

Figure 2. Two neurons retrogradely labeled with the fluorescent dye RITC in a 3-month-old septal graft that was co-grafted with the hippocampus. A process filled with the tracer is indicated by the arrow. Scale bar, $40 \mu \mathrm{m}$.

term series of grafts. Short-term transplants stained with toluidine blue in the plastic sections or stained with cresyl violet in frozen sections consisted of thousands of neurons (Fig. $5 a, b, d$ ). In contrast, sections of the 12- and 18-month-old septal grafts had very few neurons (Fig. 5c). The neuropil content was also corresponding reduced in the long-term transplants.

Neurofilaments. The sciatic nerves were focally distended by the short-term grafts and consisted of whorls of densely packed axon profiles stained by the RT97 antibody (Fig. 6a). RT97positive perikarya were also evident as early as 1 month after grafting. Host axons (degenerative and regenerative profiles) surrounded the outside of the grafts in the PNS matrix.
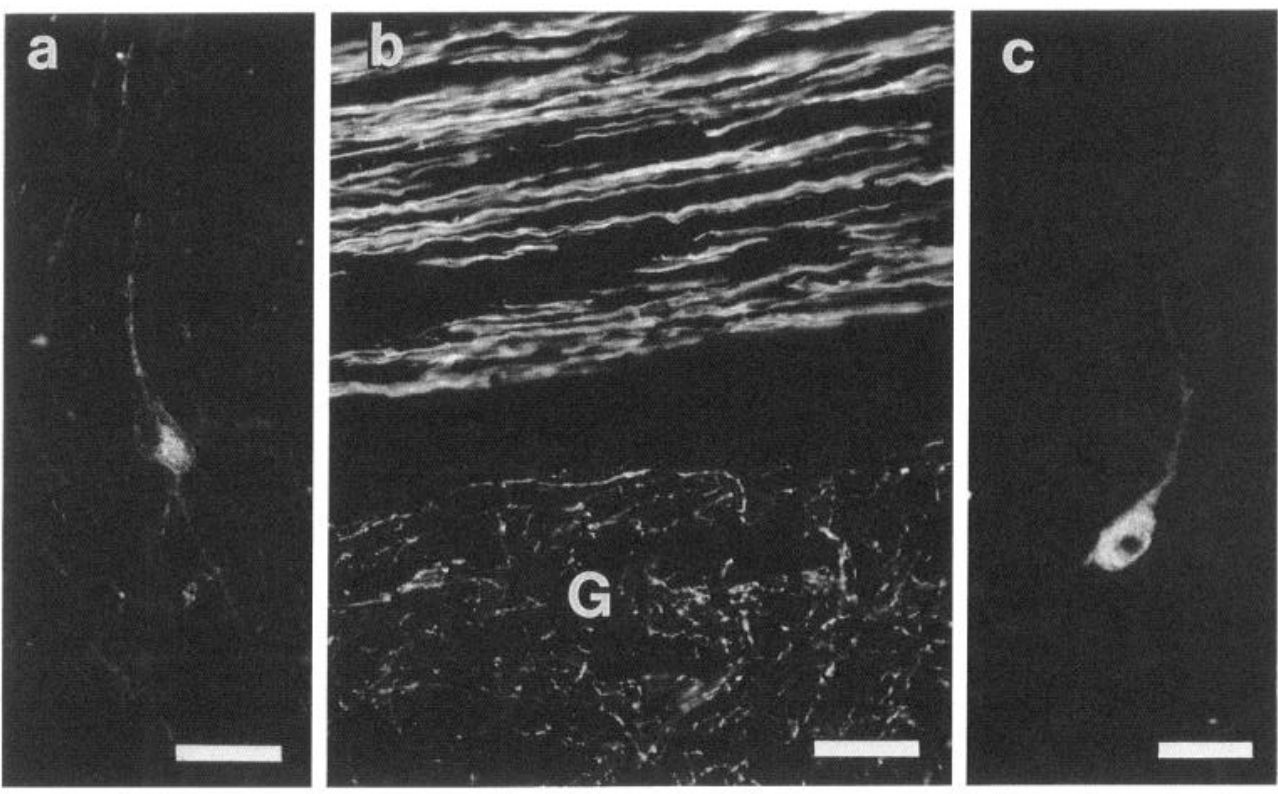

Figure 3. Identification of basal forebrain neurons with the 192-IgG and CAT antibodies in the septal grafts. $a$, Typical staining of a septal/diagonal band neuron with the $192-\mathrm{IgG}$ directed against the NGF receptor. $b$, Intensely fluorescent Schwann cell columns of the host peripheral nerve form the upper border of a septal graft. Delicate 192$\mathrm{IgG}$-positive fibers are evident in the graft $(G)$ neuropil. $c$, Neuron with strong immunoreactivity to the CAT antibody. Scale bars: $a, 40 \mu \mathrm{m} ; b, 50 \mu \mathrm{m}$; $c, 30 \mu \mathrm{m}$. 


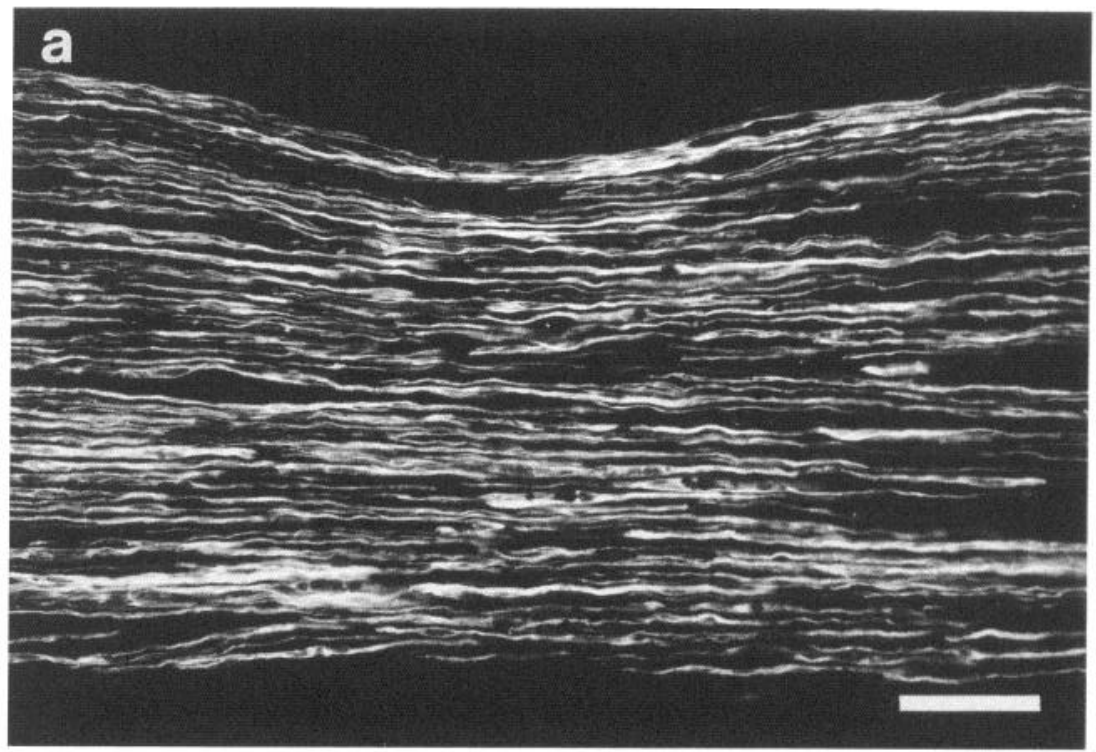

Figure 4. Comparison of NGF receptor expression in 1 -month-old $(a)$ and 18-month-old $(b)$ host sciatic nerves immediately distal to the grafts and approximately $3-4 \mathrm{~cm}$ distal to the transection site. Arrows mark autofluorescent material present in the "aged" sciatic nerve. Scale bars, $75 \mu \mathrm{m}$.

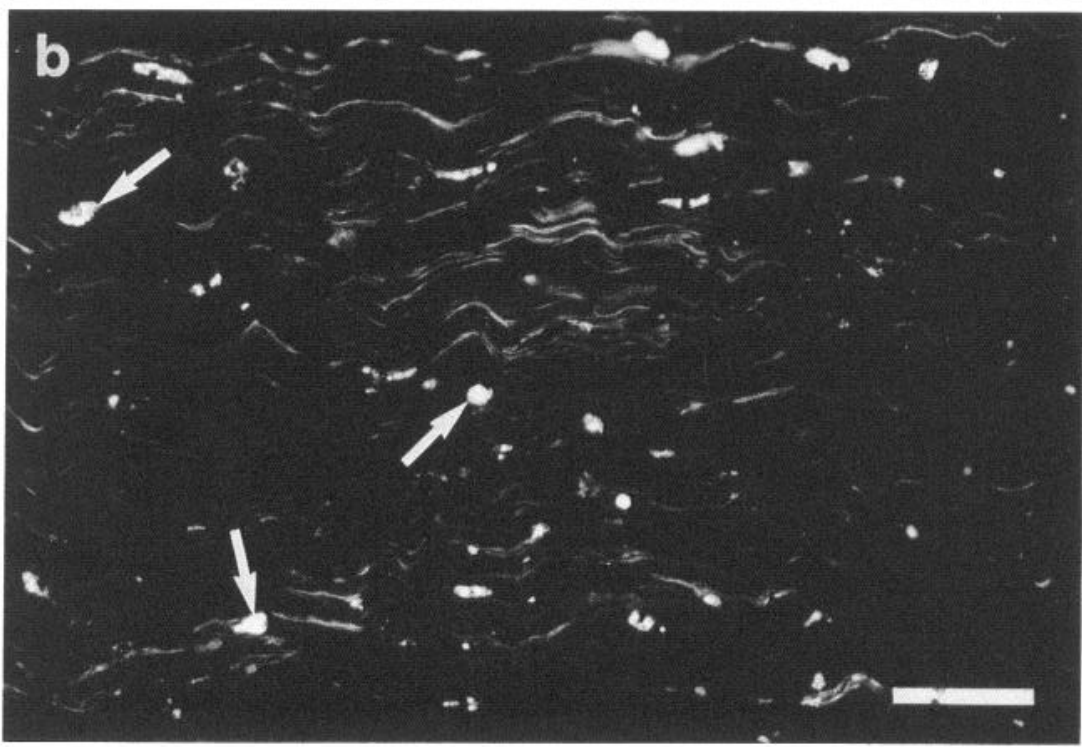

The SMI-32 (nonphosphorylated intermediate and heavy neurofilament units) antibody recognized neuronal cell bodies, dendrites, and proximal axonal segments (Fig. 6d). Unlike the RT97 results, the degenerative host axons in the peripheral nerve around the grafts showed no SMI-32 immunoreactivity when analyzed 1 month after transplantation. Regenerative host axons, present in the sciatic nerves after 3 months, were identified with the SMI-32 antibody. The host axons were easily distinguished in these preparations due to their large diameter and uniform, parallel orientation (Fig. 6b).

A reduction in RT97 staining was observed when studying the 6-18-month-old septal grafts (Fig. 7a,b). The high density of fine, delicate axonal processes was replaced by a lower density of immunostained fibers, and many of these fibers were thickened. Axon profiles were often short or focally swollen and showed end-bulb swellings (Fig. $7 b$ ).

Microtubule-associated proteins. The high-molecular-weight MAP2 clearly outlined the extent of the grafts in the peripheral nerve matrix. Individual cell bodies and their arbors were immunostained (Fig. 8a). Large and small immunoreactive neu- ronal perikarya were distributed throughout the transplants. Immunofluorescent processes were particularly dense in the shortterm implants. The dendrite arbors at the periphery of the grafts tended to be oriented parallel with the Schwann cell columns. In the long-term grafts, dendrite arbor branching and density were dramatically reduced (Fig. $8 c$ ). The immunoreactivity in the neurons was often weak in comparison to the short-term grafts.

A moderate to light density of axons showed immunoreactivity to the 5E2 antibody (tau) in this group of transplants. No neuronal cell bodies were immunostained. Abnormal immunostaining, indicated by very thick, short, and curly fibers, was numerous in the 12-18-month-old grafts (Fig. $8 b$ ).

Glial fibrillary acidic protein. The degree of glial fibrillary acidic protein (GFAP) immunoreactivity paralleled the age of the single septal grafts (Table 3; compare Fig. $9 a, b$ ). In sections of the long-term transplants double labeled for neurofilament (RT97) and GFAP localization, the areas with reduced RT97 labeling showed intense GFAP staining. The margins of all grafts tended to show increased staining relative to the central areas. 

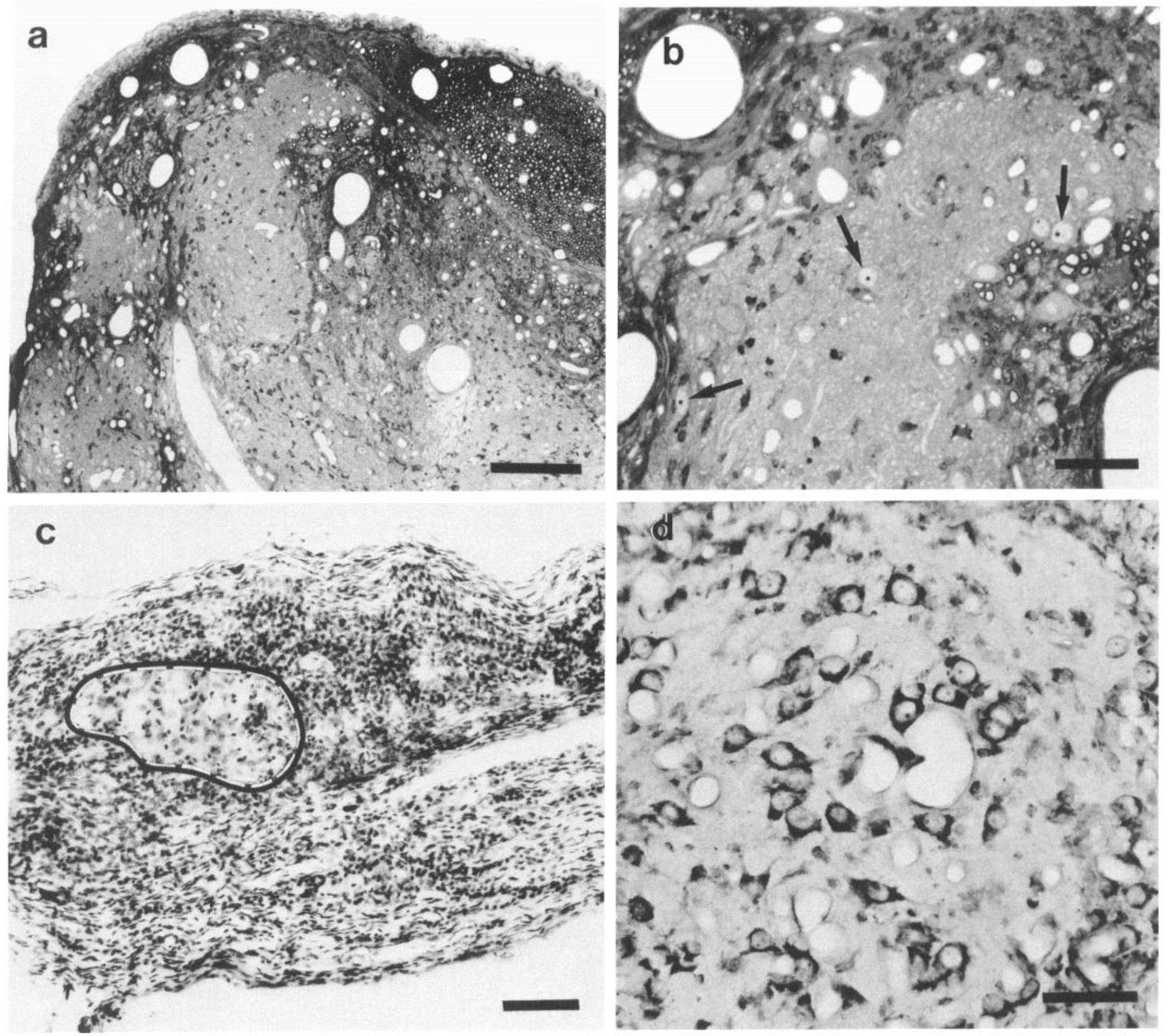

Figure 5. Light micrographs of short- and long-term grafts. $a$, Semithin section of a 3-month-old single septal graft stained with toluidine blue. This graft fills the nerve interior and measured more than $1.0 \mathrm{~mm}$ in width. Numerous blood vessels and host myelinated axons in the upper right quadrant are prominent. The pale area of the transplant represents the neuropil. $b$, Higher magnification of $a$ illustrating graft neurons (arrows) with prominent nucleoli. $c$, Cryostat section of an 18 -month-old single septal graft containing few $(<50)$ neurons. The line marks the boundary of this shrunken transplant within the sciatic nerve. $d$, Neurons in a short-term (3-month-old) single hippocampal graft stained with cresyl violet. Scale bars: $a, 150 \mu \mathrm{m} ; b$ and $d, 50 \mu \mathrm{m} ; c, 100 \mu \mathrm{m}$.

\section{Single hippocampal grafts}

The short- and long-term grafts of the hippocampal formation were relatively indistinguishable when examined with the cytoskeletal antibodies at the lower and upper limits of survival. The large size of these transplants was apparent at all ages. Expected patterns of neurofilament and MAP staining in the 1month-old grafts were also prominent in the 18-month-old cases. Large masses of tissue consisting of whorls of densely packed RT97-positive processes (Fig. 10b), and numerous SMI-32-labeled neurons were identified. Dendrite arbors were clearly visualized in all ages of the hippocampal grafts examined with
MAP2. Moderate axonal immunoreactivity to the 5E2 characterized areas in the grafts.

\section{Septal plus hippocampal grafts}

When the septum was co-grafted with the hippocampus, CATand 192-IgG-positive neurons were present in all short- and long-term septal transplants. Notably, more sections had to be examined in the long-term preparations to identify these neurons-likely reflecting a slow, gradual fallout. Introduction of the hippocampal grafts clearly increased the final volume of the septal grafts (Table 2, Fig. 11). In striking comparison, the agematched septal and substantia nigra grafts were extremely re- 
Table 2. Estimated reference volumes $\left(\mathrm{mm}^{3}\right)$ of the septum or septal portion of the combined grafts after short-term (1-3 months) and long-term (12-18 months) survival in the sciatic nerves

\begin{tabular}{|c|c|c|c|}
\hline & Single septum & $\begin{array}{l}\text { Septum }+ \\
\text { hippocampus }\end{array}$ & $\begin{array}{l}\text { Septum + } \\
\text { substantia } \\
\text { nigra }\end{array}$ \\
\hline \multirow[t]{3}{*}{ 1-3 months } & 1.13 & 0.77 & 0.66 \\
\hline & 0.72 & 1.26 & 1.01 \\
\hline & 1.23 & $\underline{1.80}$ & $=$ \\
\hline $\bar{x} \pm \mathrm{SEM}$ & $1.03 \pm 0.16^{a}$ & $1.28 \pm 0.29^{b}$ & $0.84 \pm 0.17^{c}$ \\
\hline \multirow[t]{3}{*}{$12-18$ months } & 0.024 & 1.80 & 0.015 \\
\hline & 0.018 & 2.67 & 0.064 \\
\hline & $\underline{0.050}$ & $\underline{1.19}$ & - \\
\hline $\bar{x} \pm \mathrm{SEM}$ & $0.031 \pm 0.01$ & $1.88 \pm 0.42$ & $0.04 \pm 0.02$ \\
\hline
\end{tabular}

The Cavalieri method (Cavalieri, 1966) was used to estimate the total reference volume $\left(\boldsymbol{V}_{\mathrm{ref}}\right)$ from alternate section profiles through the grafts stained with cresyl violet. The sections were magnified with a Zeiss projection microscope, and a Bioquant System IV program interfaced with a digitizing tablet was used to measurc the areas of the graft tracings and then calculate a mean transplant area $(\bar{a})$. Then, $V_{\text {ref }}=a \times t \times s$, where $t=$ section thickness and $s=$ number of sections through the transplant (see Coggeshall, 1992). Statistical comparisons between the groups were made with the Student's $t$ test.

${ }^{a} P<0.001$ versus single septum (12-18 months); $P<0.01$ versus septum + substantia nigra (12-18 months).

${ }^{n} P<0.0001$ versus single septum (12-18 months); $P<0.01$ versus septum + substantia nigra (12-18 months).

$P<0.0001$ versus single septum (12-18 months); $P<0.02$ versus septum + substantia nigra (12-18 months).

duced in size when examined after 12-18 months. In the hippocampal portion, 192-IgG-immunolabeled fibers were also seen. Although both the hippocampal and septal portions were examined, the following results are concerned primarily with the septal portion of the co-grafts. In short, expected patterns of neurofilament (RT97 and SMI-32) staining were seen in the hippocampal tissues. Dendrite arbors were clearly visualized in all ages of the hippocampal grafts studied with MAP2. Typical immunoreactivity to the $5 \mathrm{E} 2$ characterized the hippocampal cografts.

Neurofilaments. Septal co-grafts revealed normal, robust patterns of RT97 immunoreactivity when examined after short and long time periods (Fig. 10a). Axonal tracts between the septum and hippocampus were labeled with the RT97 antibody (Fig. $6 c$ ). These axons, very small in diameter compared with the large myelinated host axons, could be followed out of the grafts into the PNS matrix. In contrast to the single septal grafts, RT97positive cell bodies were not seen before 6 months of survival and only occasionally after this age. Since the SMI-32 antibody does not stain all neurons, or all dendrites (Campbell and Morrison, 1989), it was difficult to assess accurately specific changes as a function of graft age with this monoclonal antibody.

MAPs. Spatial distributions of immunoreactivity to MAP2 seen in the long-term septal portion of the co-grafts were similar
Table 3. Estimated number of neurons in the septal grafts or septal portion of the combined transplants after 1 and 12 months of survival

\begin{tabular}{|c|c|c|c|}
\hline & Single septum & $\begin{array}{l}\text { Septum + } \\
\text { hippocampus }\end{array}$ & $\begin{array}{l}\text { Septum + } \\
\text { substantia } \\
\text { nigra }\end{array}$ \\
\hline \multirow[t]{3}{*}{1 month } & 3988 & 5351 & 2019 \\
\hline & 3455 & 3767 & 3641 \\
\hline & 2595 & 6462 & - \\
\hline $\bar{x} \pm \mathrm{SEM}$ & $3346 \pm 406^{a}$ & $5193 \pm 782^{b}$ & $2830 \pm 811^{\circ}$ \\
\hline \multirow[t]{3}{*}{12 months } & 92 & 4464 & 34 \\
\hline & 49 & 5420 & 62 \\
\hline & 50 & 3022 & $=$ \\
\hline $\bar{x} \pm \mathrm{SEM}$ & $\overline{64} \pm 14$ & $\overline{4302} \pm 696$ & $\overline{48} \pm 14$ \\
\hline
\end{tabular}

The disector method (Sterio, 1984) was used to estimate the number of neurons in the grafts. The disector provides a numerical count that is unbiased by the shape or size of the cells in question (Brændgaard and Gundersen, 1986). Each value represents the estimated number of neurons $(N)$ in a different graft where $N=N_{\mathrm{r}} \times V_{\text {ref }}$ (Coggeshall, 1992). See Table 2 for $V_{\text {ref }}$ calculations. $N_{r}=\mathrm{EQ} / \Sigma V_{\text {dis }}$, where EQ represents the number of ncuronal nuclei counted in the total volume of the disectors $\left(\Sigma V_{\text {dis }}\right)$. Statistics were performed with a Student's $t$ test. ${ }^{a} P<0.0001$ versus single septum (12 months); $P<0.002$ versus septum + substantia nigra (12 months).

${ }^{\circ} P<0.05$ versus single septum (1 month); $P<0.0001$ versus single septum (12 months); $P<0.001$ versus septum + substantia nigra (12 months).

' $P<0.0001$ versus single septum (12 months); $P<0.003$ versus septum + substantia nigra (1 2 months).

to the short-term cases. The regression of arbors in the longterm single septal transplants was not apparent in this group of grafts.

$5 \mathrm{E} 2$ (tau) outlined axons in the neuropil of the grafts. The immunoreactivity tended to occur in patches within the grafts rather than in an even distribution as seen with the RT97 antibody. In the long-term grafts, light immunoreactivity was observed occasionally observed in the neuronal perikarya. The immunofluorescent reaction in the long-term grafts was at times very weak, requiring high magnification to visualize the processes.

GFAP. An even distribution of astrocyte processes characterized the serics of scptal grafts in combination with the hippocampal formation. Although some isolated zones with noticably thick profiles of GFAP fibers were seen in the longerterm combined grafts, the intensity of immunofluorescence was far less than the single isolated septal transplants (Table 4).

\section{Septal plus substantia nigra grafts (control grafts)}

The characteristics of the septal grafts when combined with the substantia nigra were similar to the results of the single septal implants; that is, long-term septal graft volume was not increased when co-grafted with the nigral tissue (Table 2). The septum showed a progression of degenerative cytoskeletal changes, paralleling graft age, that resulted in immunocytochemical staining patterns resembling the morphology of the

Figure 6. Phosphorylated and nonphosphorylated neurofilament immunoreactivity in longitudinal sections of septal and hippocampal grafts. $a$, Short-term (1-month-old) single septal graft. Dense immunofluorescent arrays of RT97-positive processes occupy all regions of the graft. $b$, Longterm (1-year-old) single hippocampal graft visualized by RT97 immunoreactivity. Arrows mark host peripheral axons. $c$, Fine axonal processes following the Schwann cell columns in the sciatic nerve between the septal and hippocampal parts are visualized by immunoreactivity to the RT97 antibody. Axons with similar morphology were also seen to leave the margins of the grafts and continue into the peripheral nerve matrix. $d$, Typical appearance of neurons in a short-term single septal graft reacted with the SMI-32 antibody that recognizes a nonphosphorylated neurofilament epitope. Scale bars: $a$ and $b, 250 \mu \mathrm{m} ; c, 75 \mu \mathrm{m} ; d, 50 \mu \mathrm{m}$. 


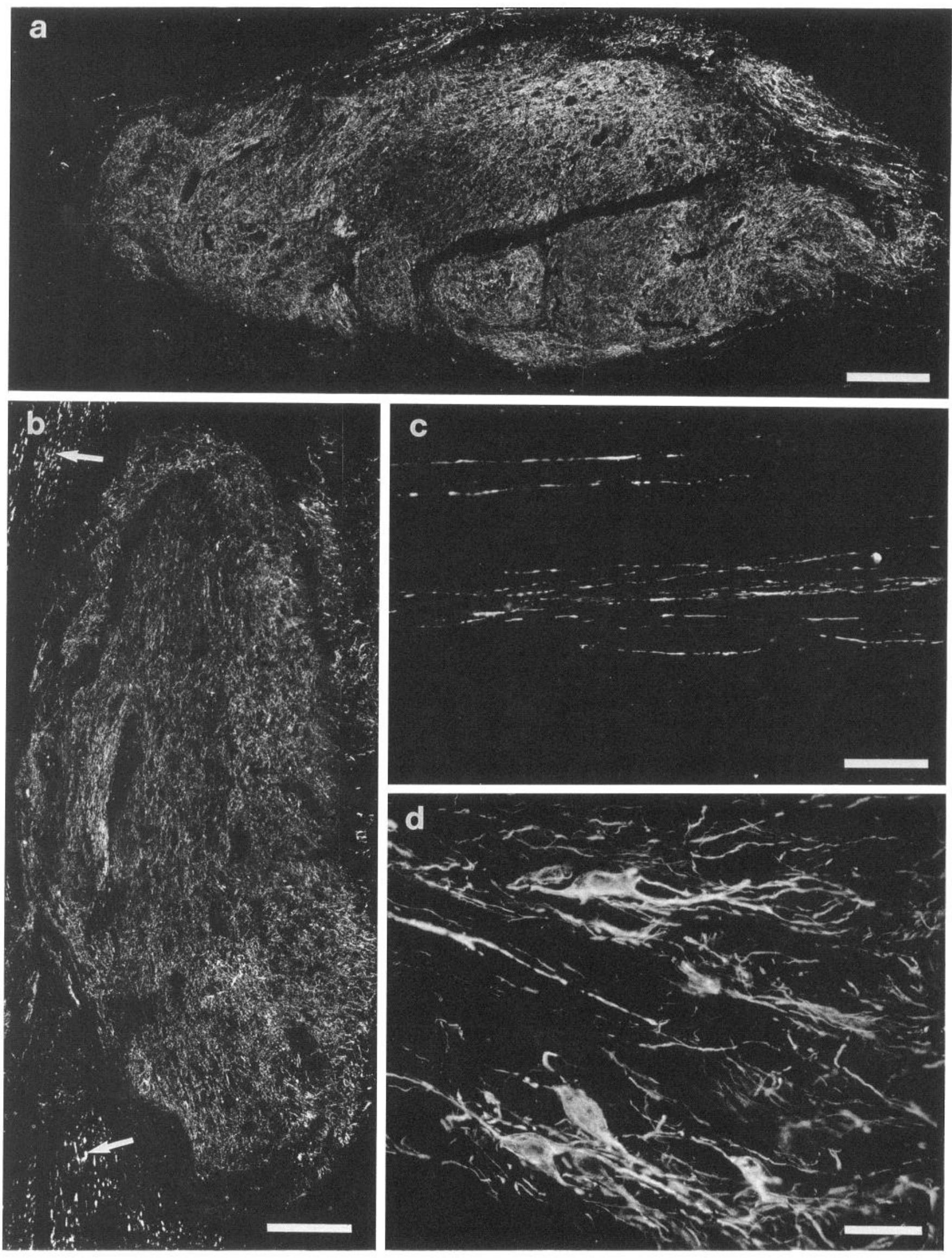




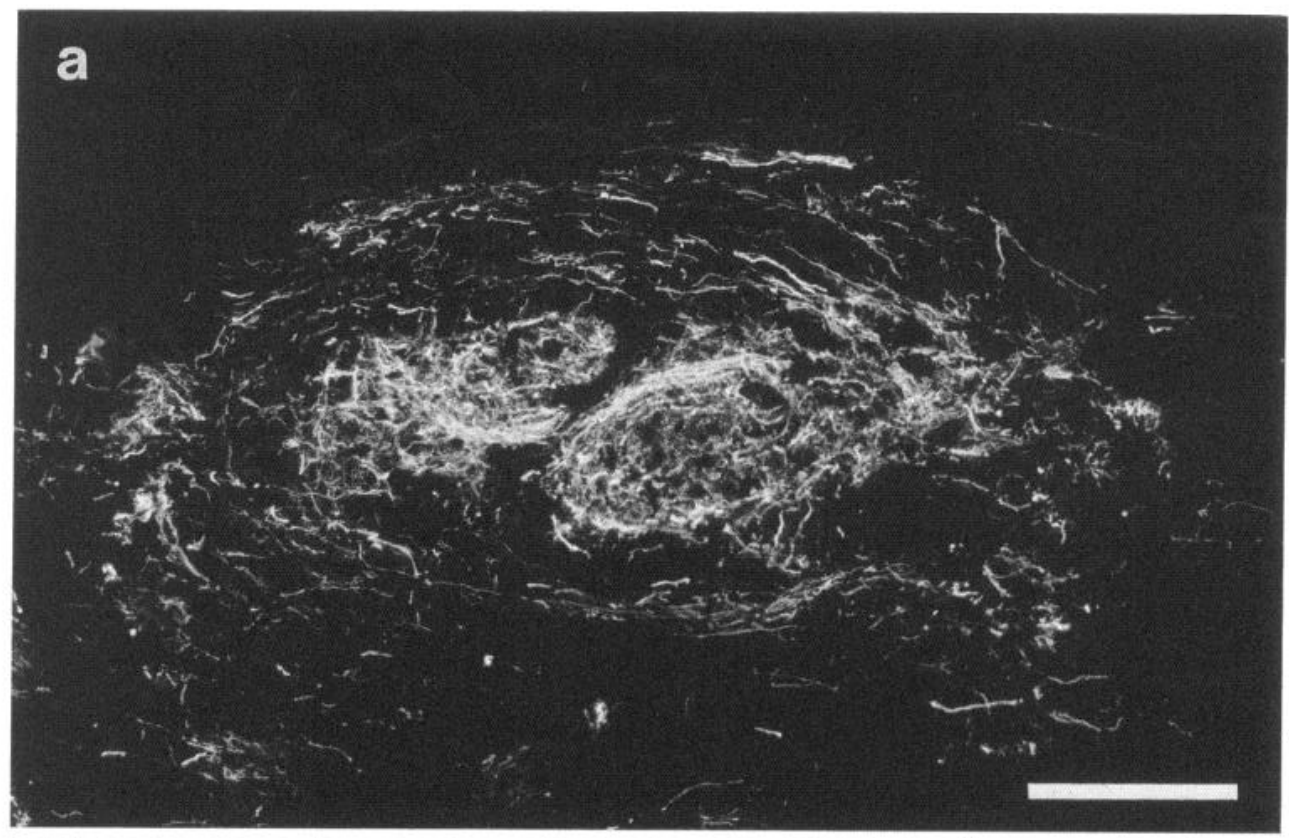

Figure 7. Abnormal neurofilament immunoreactivity in isolated long-term single septal grafts. $a$, One-year-old graft identified with the monoclonal RT97. $A$ reduction in the density of stained processes and thickened fibers characterize the long-term grafts. $b$, Region of a septal graft shows a dramatic reduction in RT97 immunoreactivity. The open arrow marks a neuron with RT97 perikaryal staining, and the solid arrow shows a swollen axon with a possible end-bulb swelling. $c$, Neuron with intense flamelike perikaryal immunoreactivity to the RT97 antibody. Scale bars: $a, 200 \mu \mathrm{m} ; b, 50 \mu \mathrm{m} ; c, 40 \mu \mathrm{m}$.
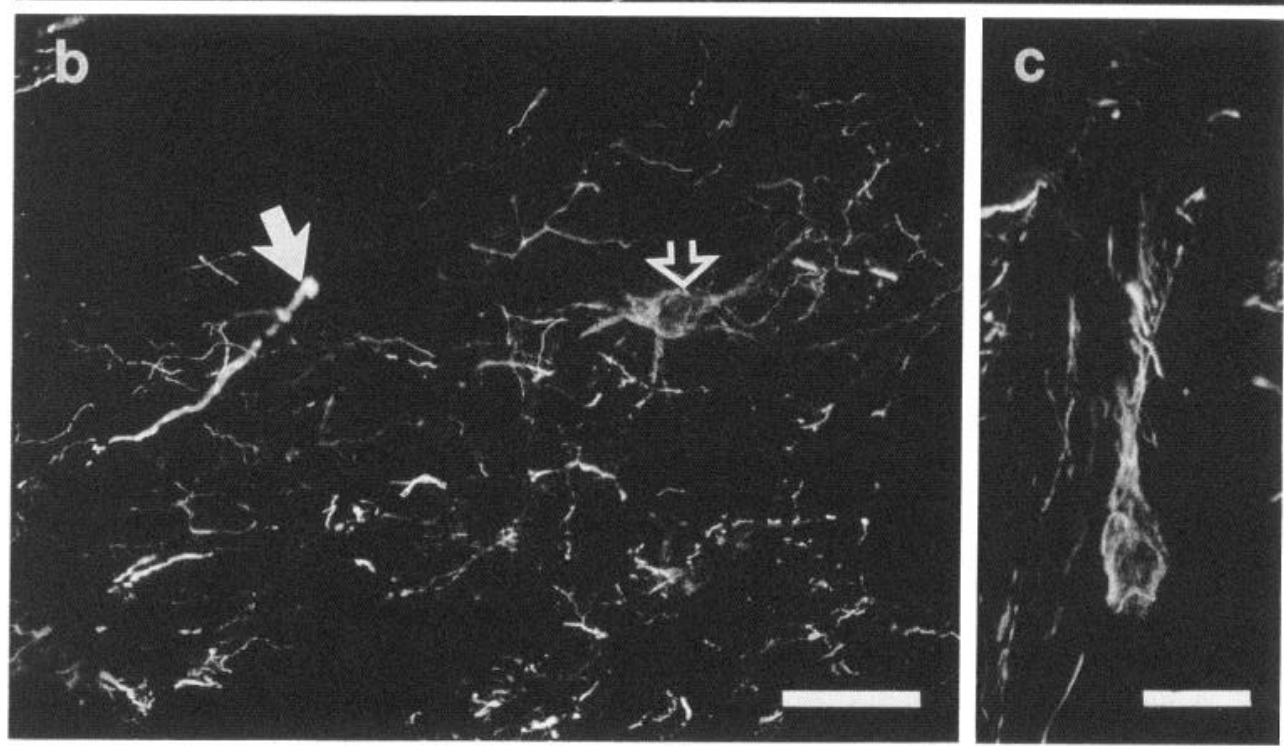

single implants. No protection against abnormal immunoreactivity was offered by the substantia nigra.

\section{Discussion}

The present experiments have illustrated that neuronal interactions between source and target CNS tissues play a role in the maintenance of a normal cytoskeleton. The important and novel aspects of this study center on the finding that abnormal cyto- skeletal characteristics develop when neurons cannot interact with the correct target or when the neurons have no CNS target for interaction. Only when the appropriate (hippocampal) CNS region was co-grafted with the septum were the aberrant cytoskeletal features (monitored by immunocytochemistry) prevented. In addition, the absence of extensive abnormal cytoskeletal change paralleled the prolonged survival of septal neurons in the co-graft preparations. Prominent changes in the isolated

Table 4. Relative intensity of GFAP immunofluorescence in the septum and hippocampus when examined after short and long survival times in the peripheral nerves

Septum

\section{Short term}

$$
\text { (1-3 months) }
$$

Long term

(12-18 months)
$++$

$+++$
Hippocampus

Septum + hippocampus
Septum + substantia nigra 

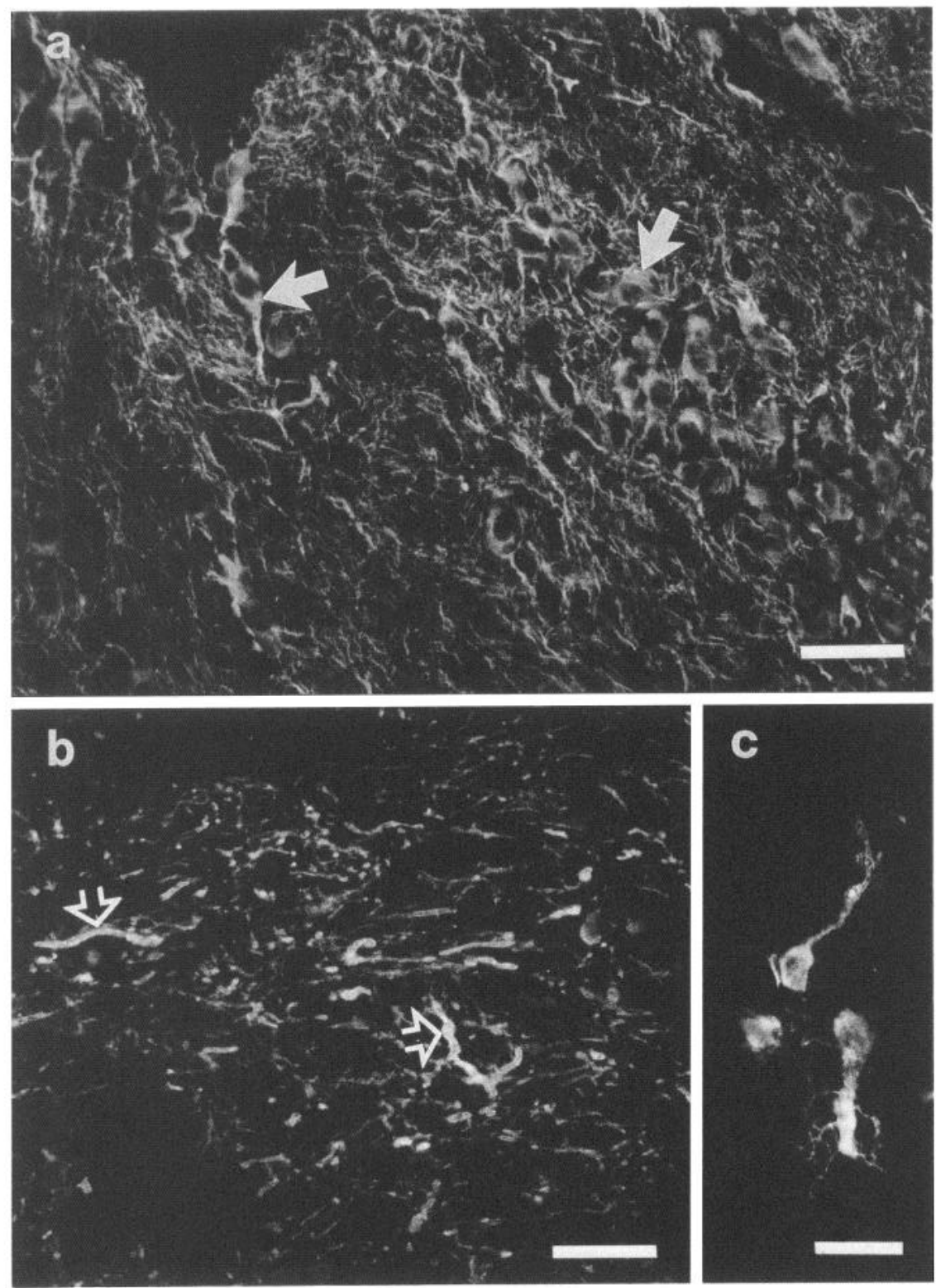

Figure 8. MAP immunostaining in short- and long-term grafts. $a$, Neuronal somata (indicated by arrows) and dense dendrite arbors show strong immunoreactivity to the MAP2 antibody in a short-term transplant. $b$, Tau immunoreactivity to the antibody $5 \mathrm{E} 2$ in a 1-year-old septal graft. Arrows point to abnormally thick, curly fibers. $c$, Atrophy of the dendrite arbors outlined by the MAP2 in a 1-year-old graft. Scale bars: $a, 50 \mu \mathrm{m} ; b$ and $c, 40 \mu \mathrm{m}$. long-term (12-18-month-old) septal tissues in this graft system are summarized as follows:

(1) graft shrinkage and neuropil reduction,

(2) neuronal death,

(3) loss of CAT and NGF receptor immunoreactivity,

(4) shift in expression of the phosphorylated neurofilaments from the axon to the somata,

(5) regression of the dendrite arbors indicated by MAP2 staining,

(6) appearance of "curly" or "kinked" fibers outlined by tau immunoreactivity, and

(7) increase in the density of GFAP immunostaining.

\section{Regulation of neuronal survival by targets and trophic factors}

Application of trophic factors in vivo and in vitro (Hofer and Barde, 1988; Oppenheim et al., 1988, 1991; Eichler and Rich, 1989) has emphasized the importance of neurotrophic factors in regulating neuronal survival during development. Neuro- trophic factors, including the prototype NGF, are produced from axonal targets and from non-neuronal supporting cells. When the polypeptide NGF is infused into the adult rodent and primate brain, the degeneration of axotomized basal forebrain cholinergic neurons can be prevented (Hefti, 1986; Williams et al., 1986; Kromer, 1987; Koliatsos et al., 1990; Tuszynski et al., 1990b). Ciliary neurotrophic factor (Oppenheim et al., 1991), brain-derived neurotrophic factor, and neurotrophin-3 (Leibrock et al., 1989; Ernfors et al., 1990; Hohn et al., 1990; Jones and Reichardt, 1990; Maisonpierre et al., 1990; Rosenthal et al., 1990) are additional factors that favorably influence the survival of select neuronal populations.

The cholinergic neurons that project from the medial septal nucleus to the hippocampus provide a good system to assess the importance of target-derived support, since this subpopulation of basal forebrain neurons has only one main projection to the hippocampus (Amaral and Kurz, 1985). Retrograde fluorescent tracers applied to the hippocampus have been used to show that substantial numbers of septal neurons die when their 
Figure 9. GFAP immunoreactivity in short- and long-term septal grafts. $a$, Strong GFAP staining at the graft periphery contrasts with relatively normal astrocyte staining in the graft interior. Individual glial cells (arrows) are evident in this short-term graft. $b$, Intense immunostaining in all areas of the grafts characterize the long-term single grafts. The entire transplant is shown. Scale bars: $a, 75 \mu \mathrm{m} ; b, 150 \mu \mathrm{m}$.
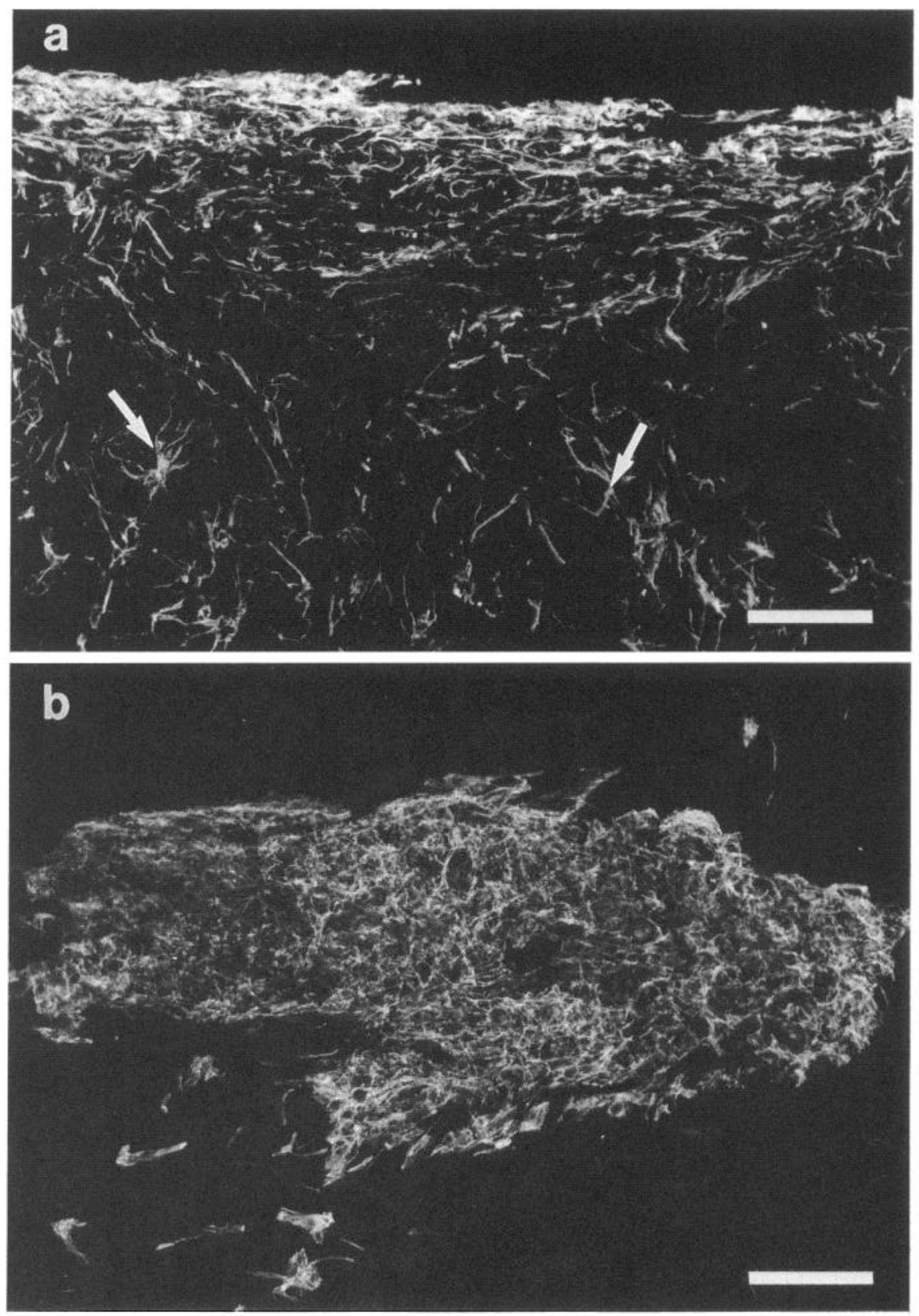

axons, which project through the fimbria-fornix, are lesioned (O'Brien et al., 1990; Tuszynski et al., 1990a). Contrary to this interpretation, Peterson et al. (1990) have offered data suggesting that the majority of medial septal and ventral diagonal band neurons that project to the hippocampus do not die within 10 weeks after axotomy, but rather shrink and become undetectable by routine histological methods. In agreement with this data, Hagg et al. (1989) indicate that at least half of the apparent loss of cholinergic medial septal neurons upon axotomy is due to a loss of markers including CAT and NGF receptors rather than to actual neuronal cell death. Interestingly, this same population of neurons, however, do not die after their target neurons in the hippocampus are destroyed (Sofroniew et al., 1990).

Gähwiler and co-workers (Gähwiler and Hefti, 1984; Gäwiler and Brown, 1985) have studied cholinergic interactions with organotypic cultures of fetal septum and hippocampus. Most recently, a role for NGF in the long-term maintenance of cholinergic septal neurons and the septohippocampal projection has been shown in vitro (Gähwiler et al., 1990).

In the present study, target support from the hippocampus protected septal neurons from a series of cytoskeletal alterations that paralleled neuronal death. Basal forebrain grafts in the PNS with no appropriate target or placement of the septal transplants with the substantia nigra (nontarget area) resulted in a number of abnormal filamentous changes, extensive neuronal loss, and a reduction in graft size. It is noteworthy that single hippocampal grafts under the same conditions did not undergo the morphological changes that were evident in the septum. However, occasional aberrant neurofilament immunoreactivity was noted in the hippocampal transplants, likely representing a process of natural cell death. Hence, different regions of the CNS in the PNS proceed through the described cytoskeletal changes at dif- 

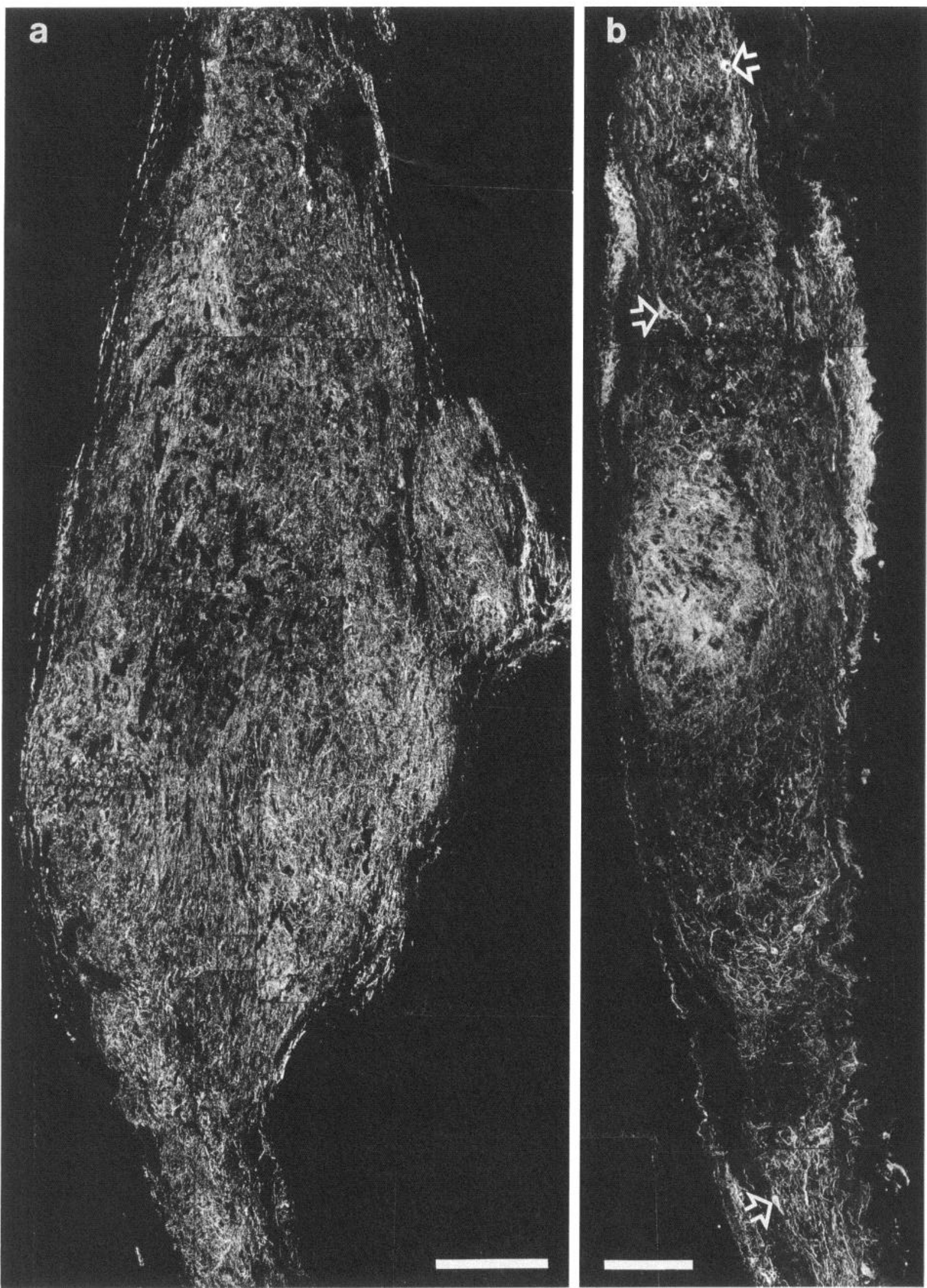

Figure 10. Long-term co-grafts of the septum and hippocampus. $a$, Neurofilament immunostaining in the septal portion of a 12-month-old preparation. The RT97 staining does not appear different from the staining observed in the short term (compare Fig. $6 a$ ). Note the large size of the transplant and the distention of the sciatic nerve by the CNS tissue. $b$, Longitudinal section of the hippocampal co-graft stained with the SMI32 antibody. Neuronal cell bodies (arrows) and dendrite arbors are numerous. Scale bars: $a, 400 \mu \mathrm{m} ; b, 250 \mu \mathrm{m}$. 


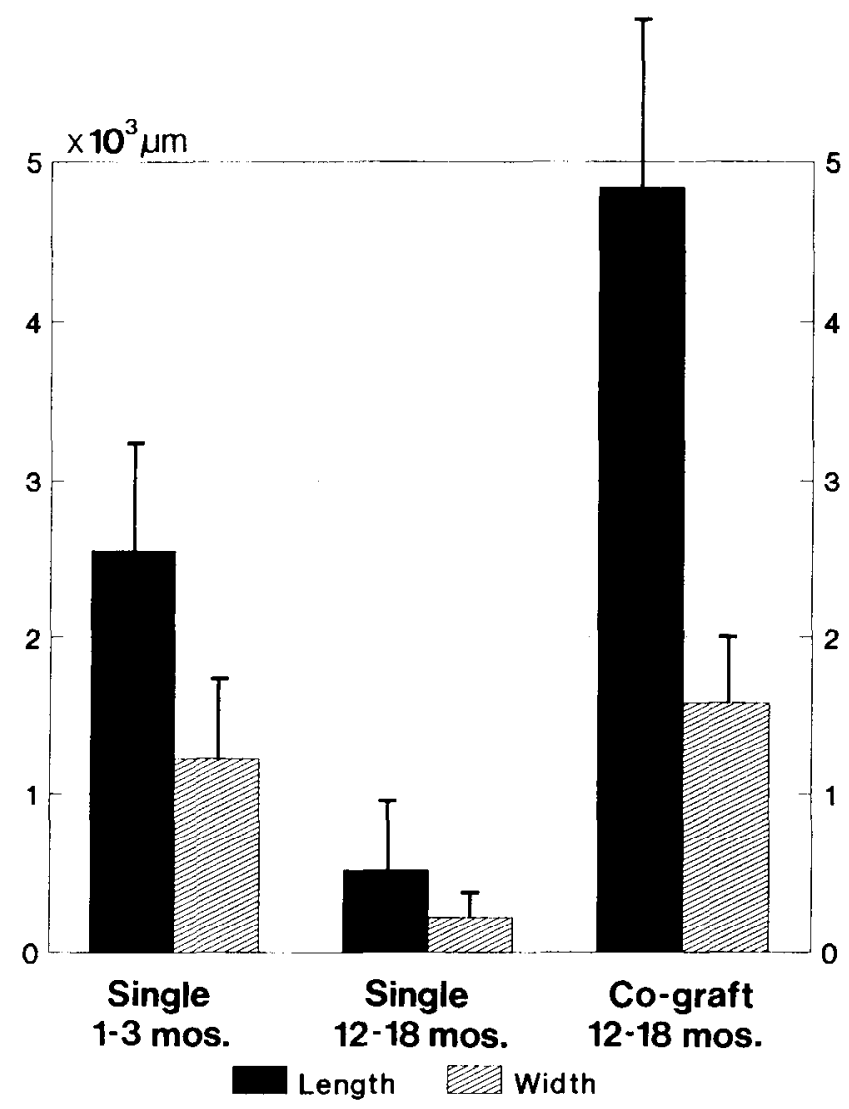

Figure 11. Septal graft size as a function of age when transplanted alone or in combination with the hippocampus. Length and width dimensions (maximum equatorial distance) of the grafts ( $n=3$ for each group) were made from the photographic prints of the transplant sections labeled with RT97 or SMI-32 antibodies. Values are the mean \pm SEM.

ferent rates. Barde (1989) has indicated that hormonal influences, the number and appropriateness of the synaptic contacts made by the neurons, and interactions of neurons and their axons with components of the extracellular matrix are likely to be involved with the regulation of neuronal survival. It is interesting to note that in a study designed to examine the effects of target and nontarget cells on grafted mesencephalic neurons, the addition of striatal target neurons was shown to have a stimulatory effect on the morphological development of the transplanted fetal dopamine cells (Brundin et al., 1986).

The importance of axonal targets in the maintenance of a normal cytoskeleton has also been obtained from morphological studies of intracerebral and intraocular transplants. When neurons in septal grafts to the CNS are observed to extend long axons that contact the host hippocampus, abnormal neurofilament (RT97) immunoreactivity in neuronal somata is not observed (Doering et al., 1991a). Conversely, grafted neurons with abnormal perikaryal expression of this epitope in these same animals are not seen with axonal projections directed toward a target. Results from single and combined grafts of the septum and the hippocampus in the anterior chamber of the eye also strongly suggest that targets are involved in the normal spatial distributions of cytoskeletal proteins. Abnormalities in axonal and dendritic immunoreactivity, evident in single 1-year-old septal implants, can be prevented when co-grafted with the hippocampal formation in oculo (Doering et al., 1991b).

\section{Changes in the spatial distribution of MAPs}

The phosphoprotein tau and MAP2 are two major classes of MAPs that are thought to regulate microtubule assembly, structure, and function (Lee et al., 1988). Immunohistochemical studies have shown that tau (low-MW MAP) is confined to the axonal domain (Binder et al., 1985; Trojanowski et al., 1989) and that MAP2 (high-MW MAP) is found in the cell body and dendrite compartments (DeCamilli et al., 1984; Vallee et al., 1984; Garner et al., 1988). This spatial distribution for low- and high-MW MAPs was confirmed in the present study.

In the human cerebral cortex, axonal patterns of tau immunoreactivity are seen as discrete bundles with specific direction that originate from tracts in the white matter. The fiber patterns observed with tau resemble the cytoarchitecture of axons with myelin-specific stains (Kowall and Kosik, 1987). Tau protein in the aging CNS and in Alzheimer's disease can associate with neurofibrillary tangles and other abnormal inclusions (Kosik et al., 1986; Joachim et al., 1987). A variety of monoclonal antibodies with epitopes that span the tau protein have also been shown to react with tangles (Kosik et al., 1988; Goedert et al., 1989). The antibody 5E2, when applied to brain tissue affected by Alzheimer's disease, defines thickened, short, and kinked neurites (Kowall and Kosik, 1987). In addition, the intensity of immunoreactivity is reduced and the pattern of the fiber bundles is eliminated. The results of the present study illustrated a loss of axonal immunoreactivity as a function of graft age. Furthermore, the 5E2 and RT97 antibodies (both axonal markers) revealed segments of short and curly axons with striking similarity to the abnormal fibers recognized by tau antisera in cases of Alzheimer's disease (Kosik et al., 1986; Ohtsubo et al., 1990).

Antibodies directed against MAP2 are excellent markers to stain the entire dendrite arbors (DeCamilli et al., 1984) and offer valuable insight into the extent of the dendritic fields as a function of age. Regression of the dendrite arbors in the long-term single septal grafts was a major finding. Asymmetrical cell bodies, local swellings of the dendrite shafts, and shortening of the dendrites were all noted in the long-term single septal grafts. In contrast to the thinning of arbors and loss of dendrite density, when combined with the target the septal neurons showed robust arbor morphology. Hence, axonal, somatic, and dendritic domains of the neurons are all influenced when in isolation or when contacting the incorrect target.

\section{GFAP content parallels graft age}

In the aging rat, the GFAP content and size of astrocytes increase in different brain regions (Björklund et al., 1985). Fibrous astrocytes in the aging human cerebral cortex also significantly increase in number after the age of 70 (Hansen et al., 1987). Astrocyte proliferation and a marked enhancement of GFAP expression in glial processes in the neuropil of cerebral cortex and brain stem grafts have been shown (Björklund and Dahl, 1982; Björklund et al., 1983). With intraocular grafts of the neocortex and locus coeruleus, GFAP immunoreactivity has also been reported to be most similar to astrocytes in situ when these regions are co-grafted (Björklund and Dahl, 1982). The present experiments further confirm the notion that GFAP immunoreactivity is minimized when the neural tissue is grafted with the appropriate target. It is unknown at the present time if the increase in the GFAP density reflects a higher number of astrocytes per graft area due to tissue shrinkage or if the increase represents proliferation of the astrocytes. 


\section{Phosphorylated neurofilament changes in disease and subsequent to axonal lesions}

Monoclonal antibodies directed against phosphorylated epitopes on heavy neurofilament proteins identify hypertrophied neurons and a number of cytoskeletal abnormalities observed in Alzheimer's disease, amotrophic lateral sclerosis, and Parkinson's disease (Goldman and Yen, 1986; Haugh et al., 1986; Ulrich et al., 1987). Antibodies directed against the $M_{r} 200,000$ neurofilament subunit stain the somata of hippocampal pyramidal neurons in Alzheimer's disease (Cork et al., 1986), and the monoclonal antibody RT97 identifies the neurofibrillary tangles (Anderton et al., 1982; Ulrich et al., 1987). These observations as well as others (Sternberger et al., 1985) suggest that an abnormal distribution of the phosphorylated heavy neurofilament unit is associated with the formation of neurofibrillary tangles. The development of neurofibrillary tangles likely represents an early stage in the degeneration of neurons (Saper et al., 1985), and cell loss appears to be due to the maturation of tangles that displace normal cellular constituents. The dysfunction and death of cholinergic neurons in the basal forebrain have also been shown by Rasool et al. (1986) to be associated with extensive neurofibrillary tangle formation. The data from the present grafting model also indicate that a shift in the expression of the highly phosphorylated neurofilament from the axon to the soma is an indicator of neurons distined to die.

Several groups have illustrated the abnormal reactivity of neuronal perikarya with axon specific neurofilament antibodies after injury (Dräger and Hofbauer, 1984; Goldstein et al., 1987; Rosenfeld et al., 1987). The change from an axonal to a somata neurofilament distribution subsequent to axonal lesions has been suggested to result from alterations in neurofilament phosphorylation rather than from changes in the transport rate of phosphorylated neurofilaments (Goldstein et al., 1987).

Koliatsos et al. (1989) have used fimbria-fornix transection in the rat to study acute neurofilament changes in cholinergic neurons of the septum. They identified CAT neurons with ectopic phosphorylated neurofilaments in the perikarya at $3 \mathrm{~d}$ postlesioning. After this postoperative phase, neurons with CAT immunoreactivity could not be detected in the cells with aberrant accumulations of neurofilaments. Unlike the above experimental models, phosphorylated neurofilaments occur in the neuronal cell bodies in the present transplant system without surgical intervention or without the introduction of drugs that directly interfere with axonal transport.

\section{Final statements}

This study has illustrated that transplants of CNS in the PNS can be used to examine conditions that underlie cytoskeletal change in the process of neuronal death. The present graft paradigm is unique in that reproducible degenerative changes in selected neuronal regions can be studied within relatively short time frames and the factors that modulate these changes can be examined under controlled conditions. A primary target for change is the cytoskeleton, and the abnormal cytoskeletal changes that develop represent a stage in neuronal degeneration. From the present experiments, it is concluded that appropriate sourcetarget neural interactions can promote neuronal survival and that the correct neural target is integral to the maintenance of normal cytoskeletal architecture in neurons and astrocytes over extended time frames.

\section{References}

Amaral DG, Kurz J (1985) An analysis of the origins of the cholinergic and non-cholinergic septal projections to the hippocampal formation of the rat. J Comp Neurol 420:37-59.

Anderton BH, Breinburg D, Downes MJ, Green PJ, Tomlinson BE, Ulrich J, Wood JN, Kahn J (1982) Monoclonal antibodies show that neurofibrillary tangles and neurofilaments share antigenic determinants. Nature 298:84-86.

Barde Y-A (1989) Trophic factors and ncuronal survival. Neuron 2: 1525-1534.

Binder LI, Frankfurter A, Rebhun LI (1985) The distribution of tau in the mammalian central nervous system. J Cell Biol 101:13711378.

Björklund A, Stenevi U (1984) Intracerebral neural implants: neuronal replacement and reconstruction of damaged circuitries. Annu Rev Neurosci 7:279-308.

Björklund H, Dahl D (1982) Glial disturbances in isolated neocortex: evidence from immunohistochemistry of intraocular grafts. Dev Neurosci 5:424-435.

Björklund H, Dahl D, Haglid K, Rosengren L, Olson L (1983) Astrocytic development in fetal parietal cortex grafted to cerebral and cerebellar cortex of immature rats. Dev Brain Res 9:171-180.

Björklund II, Eriksdotter-Nilsson M, Dahl D, Rose G, Iloffer B, Olson L (1985) Image analysis of GFA-positive astrocytes from adolescence to senescence. Exp Brain Res 58:163-170.

Brændgaard H, Gundersen HJG (1986) The impact of recent stereological advances on quantitative studies of the nervous system. $J$ Neurosci Methods 18:39-78.

Bruce G, Wainer BH, Hersh LB (1985) Immunoaffinity purification of human choline acetyltransferase: comparison of the brain and placental enzymes. J Neurochem 45:611-620.

Brundin P, Isacson O, Gage FH, Björklund A (1986) Intrastriatal grafting of dopamine-containing neuronal cell suspensions: effects of mixing with target or non-target cells. Dev Brain Res 24:77-84.

Campbell MJ, Morrison JH (1989) Monoclonal antibody to neurofilament protein (SMI-32) labels a subpopulation of pyramidal neurons in the human and monkey neocortex. J Comp Neurol 282:191-205.

Cavalieri B (1966) Geomtria degli indivisibili. Torino: Unione Tipografico.

Chandler CE, Parsons LM, Hosang M, Shooter EM (1984) A monoclonal antibody modulates the interaction of nerve growth factor with PC12 cells. J Biol Chem 259:6882-6889.

Coggeshall RE (1992) A consideration of neural counting methods. Trends Neurosci 15:9-13.

Cork LC, Sternberger NH, Sternberger LA, Casanova MF, Struble RG, Price DL (1986) Phosphorylated neurofilament antigens in neurofibrillary tangles in Alzheimer's disease. J Neuropathol Exp Neurol 45:56-64.

DeCamilli P, Miller PE, Navone F, Theurkauf WE, Vallee RB (1984) Distribution of microtubule associated protein 2 in the nervous system of the rat studied by immunofluorescence. Neuroscience 11:819846.

Doering LC (1991) Transplantation of fetal CNS tissue into the peripheral nervous system: a model to study aberrant changes in the neuronal cytoskeleton. J Neural Transpl Plast 2:193-205.

Doering LC, Aguayo AJ (1987) Hirano bodies and other cytoskeletal abnormalities develop in fetal rat CNS grafts isolated for long periods in peripheral nerve. Brain Res 401:178-184.

Doering I $C$, Nilsson OG, Aguayo AJ (1991a) Abnormal perikaryal immunoreactivity to the phosphorylated heavy neurofilament unit in intracerebral basal forebrain transplants. Exp Neurol 111:1-8.

Doering LC, Eriksdotter-Nilsson M, Olson L (1991b) Spatial distributions of cytoskeletal proteins and the NGF-receptor in septal transplants in oculo: protection from abnormal immunoreactivity by hippocampal co-grafts. Neuruscience 44:381-392.

Dräger UC, Hofbauer A (1984) Antibodies to heavy neurofilament subunit detect a subpopulation of damaged ganglion cells in retina. Nature 309:624-626.

Eichler ME, Rich KM (1989) Death of sensory ganglion neurons after acute withdrawal of nerve growth factor in dissociated cell cultures. Brain Res 482:340-346.

Ernfors P, Ibánez CF, Ebendal T, Olson L, Persson H (1990) Molecular cloning and neurotrophic activities of a protein with structural similarities to $\beta$-nerve growth factor: developmental and topographical expression in the barin. Proc Natl Acad Sci USA 87:5454-5458. 
Gage FH, Armstrong DM, Williams LR, Varon S (1988) Morphological response of axotomized septal neurons to nerve growth factor. J Comp Neurol 269:147-155.

Gähwiler BH, Brown DA (1985) Functional innervation of cultured hippocampal neurons by cholinergic afferents from co-cultured septal explants. Nature 313:577-579.

Gähwiler BH, Hefti F (1984) Guidance of acetyltransferase-containing fibers by target tissue in co-cultured brain slices. Neuroscience 13: 681-689.

Gähwiler BH, Reitschin L, Knöpfel T, Enz A (1990) Continuous presence of nerve growth factor is required for maintenance of cholinergic septal neurons in organotypic slice cultures. Neuroscience 36:27-31.

Garner CC, Tucker RP, Matus A (1988) Selective localization of messenger RNA for cytoskeletal protein MAP2 in dendrites. Nature 336: 674-677.

Goedert M, Spillantini MG, Jakes R, Rutherford D, Crowther RA (1989) Multiple isoforms of human microtubule-associated protein tau: sequences and localization in neurofibrillary tangles in Alzheimer's disease. Neuron 3:519-526.

Goldman JE, Yen S-H (1986) Cytoskeletal protein abnormalities in neurodegenerative diseases. Ann Neurol 19:209-223.

Goldstein ME, Cooper HS, Bruce J, Carden MJ, Lee VMY, Schlaepfer WW (1987) Phosphorylation of neurofilament proteins and chromatolysis following transection of rat sciatic nerve. J Neurosci 7 : 1586-1594.

Hagg T, Fass-Holmes B, Vahlsing HL, Manthorpe M, Conner JM, Varon S (1989) Nerve growth factor (NGF) reverses axotomy-induced decreases in choline acetyltransferase, NGF receptor and size of medial septum cholinergic neurons. Brain Res 505:29-38.

Hansen LA, Armstrong DM, Terry RD (1987) An immunohistochemical quantification of fibrous astrocytes in the aging human cerebral cortex. Neurobiol Aging 8:1-6.

Haugh MC, Probst A, Ulrich J, Kahn J, Anderton BH (1986) Alzheimer neurofibrillary tangles contain phosphorylated and hidden neurofilament epitopes. J Neurol Neurosurg Psychiatry 49:1213-1220.

Hefti $F$ (1986) Nerve growth factor promotes survival of septal cholinergic neurons after fimbrial transection. J Neurosci 6:2155-2162.

Hofer MM, Barde Y-A (1988) Brain-derived neurotrophic factor prevents neuronal death in vivo. Nature 331:261-262.

Hohn A, Leibrock J, Bailey K, Barde Y-A (1990) Identification and characterization of a novel member of the nerve growth factor/brain derived neurotrophic factor family. Nature 344:339-341.

Joachim CL, Morris JH, Selkoe DJ, Kosik KS (1987) Tau epitopes are incorporated into a range of lesions in Alzheimer's disease. $J$ Neuropathol Exp Neurol 46:611-622.

Jones KR, Reichardt LF (1990) Molecular cloning of a human gene that is a member of the nerve growth factor family. Proc Natl Acad Sci USA 87:8060-8064.

Koliatsos VE, Applegate MD, Kitt CA, Walker LC, DeLong MR, Price DL (1989) Aberrant phosphorylation of neurofilaments accompanies transmitter-related changes in rat septal neurons following transection of the fimbria-fornix. Brain Res 482:205-218.

Koliatsos VE, Nauta HJW, Clatterbuck RE, Holtzman DM, Mobley WC, Price DL (1990) Mouse nerve growth factor prevents degeneration of axotomized basal forebrain cholinergic neurons in the monkey. J Neurosci 10:3801-3813.

Kosik KS, Joachim CL, Selkoe DJ (1986) Microtubule-associated protein tau $(\tau)$ is a major antigenic component of paired helical filaments in Alzheimer's disease. Proc Natl Acad Sci USA 83:4044-4048.

Kosik KS, Orecchio LD, Binder L, Trojanowski JQ, Lee VM-Y, Lee G (1988) Epitopes that span the tau molecule are shared with paired helical filaments. Neuron 1:817-825.

Kuwall NW, Kosik KS (1987) Axonal disruption and aberrant localization of tau protein characterize the neuropil pathology of Alzheimer's disease. Ann Neurol 22:639-643.

Kromer LF (1987) Nerve growth factor treatment after brain injury prevents neuronal death. Science 235:214-216.

Lee G, Cowan N, Kirschner M (1988) The primary structure and heterogeneity of tau protein from mouse brain. Science 239:285-288.

Leibrock J, Lottspeich F, Hohn A, Hofer M, Hengerer B, Masiakowski P, Thoenen H, Barde Y-A (1989) Molecular cloning and expression of brain-derived neurotrophic factor. Nature 341:149-152.

Maisonpierre PC, Belluscio L, Squinto S, Ip NY, Furth ME, Lindsay RM, Yancopoulos GD (1990) Neurotrophin-3: a neurotrophic factor related to NGF and BDNF. Science 247:1446-1451.
Miller CJ, Brion J-P, Calvert R, Chin TK, Eagles PAM, Downes MJ, Flament-Durand J, Haugh M, Kahn J, Probst A, Ulrich J, Anderton BH (1986) Alzheimer's paired helical filaments share epitopes with neurofilament side arms. EMBO J 5:269-276.

O'Brien TS, Svendsen CN, Isacson O, Sofroniew MV (1990) Loss of True blue labeling from the medial septum following transection of the fimbria-fornix: evidence for the death of cholinergic and noncholinergic neurons. Brain Res 508:249-256.

Ohtsubo K, Izumiyama N, Kuzuhara S, Mori H, Shimada H (1990) Curly fibers are tau-positive strands in the pre- and post-synaptic neurites, consisting of paired helical filaments: observations by the freeze-etch and replica method. Acta Neuropathol (Berl) 81:111-115.

Olson L, Seiger $\AA$, Strömberg I (1983) Intraocular transplantation in rodents. A detailed account of the procedure and examples of its use in neurobiology with special reference to brain tissue grafting. In: Advances in cellular neurobiology, Vol 4 (Fedoroff S, Ed), pp 407422. New York: Academic.

Oppenheim, RW, Haverkamp LJ, Prevette D, McManaman JL, Appel SH (1988) Reduction of naturally occurring motoneuron death in vivo by a target-derived neurotrophic factor. Science 240:919-922.

Oppenheim RW, Prevette D, Qin-Wei Y, Collins F, MacDonald J (1991) Control of embryonic motoneuron survival in vivo by ciliary neurotrophic factor. Science 251:1616-1618.

Paetau A, Elovaara I, Paasivuo R, Virtanen I, Palo J, Haltia M (1985) Glial filaments are a major brain fraction in infantile neuronal ceroidlipofuscinosis. Acta Ncuropathol (Berl) 65:190-194.

Peterson GM, Lanford GW, Powell EW (1990) Fate of septohippocampal neurons following fimbria-fornix transection: a time course analysis. Brain Res Bull 25:129-137.

Rasool CG, Svendsen CN, Selkoe DJ (1986) Neurofibrillary degeneration of cholinergic and noncholinergic neurons in the basal forebrain in Alzheimer's disease. Ann Neurol 20:482-488.

Rosenfeld J, Dorman ME, Griffin JW, Sternberger LA, Sternberger NH, Gold BG, Price DL (1987) Distribution of neurofilament antigens after axonal injury. J Neuropathol Exp Neurol 46:269-282.

Rosenthal A, Goeddel DV, Nguyen T, Lewis M, Shih A, Laramee GR, Nikolics K, Winslow JW (1990) Primary structure and biological activity of a novel human neurotrophic factor. Neuron 4:767-773.

Saper CB, German DC, White CL (1985) Neuronal pathology in the nucleus basalis and associated cell groups in senile dementia of the Alzheimer's type: possible role in cell loss. Neurology 35:1089-1095.

Seiger $\AA$ (1985) Preparation of immature central nervous system regions for transplantation. In: Neural grafting in the mammalian CNS (Björklund A, Stenevi U, eds), pp 71-77. Amsterdam: Elsevier.

Sofroniew MV, Galletly NP, Isacson O, Svendsen CN (1990) Survival of adult basal forebrain cholinergic neurons after loss of target neurons. Science 247:338-342.

Sterio DC (1984) The unbiased estimation of number and sizes of arbitary particles using the disector. J Microsc 134:127-136.

Sternberger LA, Sternberger NH (1983) Monoclonal antibodies distinguish phosphorylated and non-phosphorylated forms of neurofilaments in situ. Proc Natl Acad Sci USA 80:6126-6130.

Sternberger NH, Sternberger LA, Ulrich J (1985) Aberrant neurofilament phosphorylation in Alzheimer's disease. Proc Natl Acad Sci USA 82:4274-4276.

Taniuchi M, Johnson EM Jr (1985) Characterization of the binding properties and retrograde axonal transport of a monoclonal antibody directed against the rat nerve growth factor receptor. J Cell Biol 101: $1100-1106$

Thanos S, Vidal-Sanz M, Aguayo AJ (1987) The use of rhodamine$\beta$-isthiocyanate (RITC) as an anterograde tracer in the adult rat visual system. Brain Res 406:317-321.

Trojanowski JQ, Schuck T, Schmidt L, Lee VM-Y (1989) Distribution of tau proteins in the normal human and central peripheral nervous system. J Histochem Cytochem 37:209-215.

Tuszynski MH, Armstrong DM, Gage FH (1990a) Basal forebrain cell loss following fimbria/fornix transection. Brain Res 508:241-248.

Tuszynski MH, Sang HU, Amaral DG, Gage FH (1990b) Nerve growth factor infusion in the primate brain reduces lesion-induced cholinergic neuronal degeneration. J Neurosci 10:3604-3614.

Ulrich J, Probst A, Langui D, Anderton BH, Brion JP (1987) Cytoskeletal immunocytochemistry of Alzheimer's dementia and related diseases. Pathol Immunopathol Res 6:273-283.

Vallee RB, Bloom GS, Luca FC (1984) Differential cellular and sub- 
cellular distribution of microtubule-associated proteins. In: Molecular biology of the cytoskeleton (Borisy GB, Cleveland DW, Murphy DB, eds), pp 111-130. Cold Spring Harbor, NY: Cold Spring Harbor Laboratory.
Williams LR, Varon S, Peterson GM, Wictorin K, Fischer W, Björklund A, Gage FH (1986) Continuous infusion of nerve growth factor prevents basal forebrain neuronal death after fimbria-fornix transection. Proc Natl Acad Sci USA 83:9231-9235. 